\title{
Effective Corporate Income Tax Rates: Southern and Northern Economies of the European Union
}

\author{
Dimitris Balios (Corresponding author) \\ Department of Economics, National and Kapodistrian University of Athens, Greece \\ E-mail: dbalios@econ.uoa.gr
}

Nikolaos Eriotis

Department of Business Administration

National and Kapodistrian University of Athens, Greece

Stefanos Tantos

Department of Economics, National and Kapodistrian University of Athens, Greece

Dimitrios Vasiliou

Department of Economics, National and Kapodistrian University of Athens, Greece

Received: January 17, 2020

Accepted: February 5, 2020

Published: March 10, 2020

doi:10.5296/ijafr.v10i1.16273

URL: https://doi.org/10.5296/ijafr.v10i1.16273

\begin{abstract}
In the present study, we attempt to investigate the determinants of the effective corporate tax rate of companies of the European Union (EU) discriminating between northern and southern economies. We adopt in our analysis the period after the outbreak of the crisis in the Eurozone up today including some years before 2009 in the assessed period. Our empirical investigation is based on three alternative approaches to effective income tax rate based on accounting information. We investigate the determinants of ECITR assessing two sub-samples of firms from all the aforementioned industrial sectors for 16 member countries of Europe. The first sub-sample consists of firms from 12 member countries of "North"


European Union and the second sub-sample consists of firms from 4 member countries of "South" European Union. The analysis covers the period 2004-2016. Estimation results point out that the effective corporate income tax rate is variously affected by firm-specific determining factors for both northern and southern economies. The relation between ECITR and determining factors is ascertained to be less significant (sensitive) during the pre-crisis period in comparison with the respective empirical findings after the outburst of the economic crisis in the European Union. Empirical findings indicate that effective corporate income tax rate is more vulnerable to financial leverage for southern economies in comparison to the northern economies signaling financing structure differences between the two EU-country groups. Finally, there is evidence that there is an indisputable and positive coexistence between business profitability and tax burden.

Keywords: Effective corporate income tax rate, Accounting policies, European Union, Financial crisis

\section{Introduction}

A lengthy discussion has initiated in the relevant literature concerning economic convergence between north and south member states of Economic and Monetary Union (EMU) especially during the sovereign debt crisis, with countries funded by non-market financial sources from the troika. During last years there is a great debate about the fiscal consolidation programs in European Union (EU) and their implications to the social welfare of the EU people (Balios and Tantos, 2019). Eurozone consists of two main member states groups with fiscal as well as structural discrepancies.

The first group is the Southern countries mainly part of this is the so-called PIGS (Portugal, Italy, Greece, Spain). The Southern economies are characterised a) by high Current Account deficits as well as fiscal balance problems with an accelerating rise in the debt positions (Christodoulakis, 2009) and b) specific cultural characteristics that affect the companies' performance (Balios and Zaroulea, 2020). For instance, in case of Greece, In order to restore the Greek economy to a sustainable development path and a sustainable improvement in the living standards of the population, a major fiscal adjustment program has been adopted in recent years in order to proceed immediately with fiscal consolidation through the creation of primary surpluses. Fiscal adjustment aims to cut public consumption spending and raise tax revenues (Balios and Tantos, 2019). Instead, northern economies appear substantial surpluses, improving their competitive positions, mainly Germany (De Grauwe, 2012). A significant differentiation regarding size and composition of investments is also pointed out between two Eurozone groups. More specifically, the investments in the housing sector are more attractive than in the production sector in the Southern member states, in contrast with the northern countries where there is reverse evidence resulting to increased traded output and improvement of the trade balance. In order these imbalances to decrease across Eurozone, policy makers should implement measures which enhance convergence and competitiveness (Christodoulakis, 2009).

Research indicates that the distinction between the northern and the southern economies of 
EU is based more on growth patterns than the distinction between the center (euro core) and the euro periphery (Neven and Gouymte, 1995). Regan (2017) claims that the divergence between South and North of Eurozone is based to some extent on the different macroeconomic growth regimes. In southern economies dominate domestic demand-led models and export-led models in northern member states. External imbalances have emerged between two growth models under EMU with no evidence before EMU. Johnston and Regan (2016) ascertain that this fact is justified by the presence of two inflation adjustment mechanisms in the real exchange rate; the nominal exchange rate (in soft currency regimes) and national central banks' promotion of inflation convergence (in hard currency regimes) before EMU period. De Grauwe (2012) claims that any imbalances between southern and northern economies may be corrected by adopting "internal devaluation" policies, reducing prices and wages relative to Germany and other northern countries. However, De Grauwe (2012) asserts that this policy tends to reduce aggregate demand and domestic production resulting in deterioration of the fiscal position (government budget deficits increase) of southern countries.

Subsequently, there is a wide gap between northern and southern EU economies as it concerns in some cases both fiscal as well as structural divergences. In this context, we contribute to the existent literature by identifying the factors that affect the effective corporate income tax rates for the economies of European Union (EU) or not, by categorising into two groups: northern EU countries and southern EU countries. The determining factors of effective tax rate change depending on the period (based on the macroeconomic characteristics) and the region (North or South). In this study, there is a keen interest concerning integration and convergence in the EU which analyses not only EU member economies but also a wider European region strongly integrated with the EU.

Within the investigated period we are looking forward to having some significant conclusions regarding the impact that had or continues to have the financial crisis in the firms' performance for significantly different EU economies, particularly after 2010. The fiscal or debt crisis and the subsequent over taxation has negatively affected businesses and households during last years.

The rest of the paper is organized as follows. Section 2 provides a literature review on effective corporate income tax rate and its major determining factors. Section 3 describes the research methodology and the characteristics of the research sample. Section 4 analyses the empirical results. Section 5 summarises major conclusions, discusses research limitations and makes suggestions for future research.

\section{Literature Review}

The conventional research (Richardson and Lanis, 2007; Shevlin and Porter, 1992; Wilkie and Limberg, 1993; Plesko, 2003) has highlighted that the estimation of Effective Corporate Income Tax Rate (ECITR) is a crucial issue. It attempts to answer to questions like which taxes are taken into consideration, what is the measurement method of firm's profit and what is the robustness of these estimations (Callihan, 1994; Omer and Molloy, 1991). For instance, 
Fairfield and Jorratt De Luis, 2016) focus on the role of accrued profits retained by firms in the estimation of ECITR. They indicate that ECITR is differentiated when the income concept is broadened including not only distributed profits but also accrued profits.

Prior research estimates the ECITR based on a ratio where tax expenses of a firm, in the numerator and firm's income (profits) is measured in the denominator. The tax burden of the firms may be biased whether not appropriate definitions of both numerator and denomination are taken into consideration in the ECITR equation. Regarding numerator, some researchers (e.g. Porcano, 1986; Gupta and Newberry, 1997; Richardson and Lanis, 2007; Kim and Limpaphayom, 1998) take into account the income tax expense of firms without involving any adjustments for deferred tax expense. However, other researchers (e.g. Stickney and McGee, 1982; Omer, Molloy and Ziebart, 1993; Kern and Morris, 1992; Singh, Wilder and Chan, 1987; Zimmerman, 1983) subtract the deferred tax expense portion from the total income tax expense, attempting to reduce any reporting differences resulted by changes in deferred tax liability (Omer and Molloy, 1991).

As it concerns the denominator of the ECITR equation, the relevant research has indicated that different financial data may be taken into consideration. This may be attributed to the differences between accounting (book) income, which may be estimated in different accounting policies, and taxable income (Derashid and Zhang, 2003). For instance, some researchers (Porcano, 1986; Shevlin, 1987; Stickney and McGee, 1982; Wilkie, 1988; Wilkinson et al., 2001), use accounting (book) income after interest and before tax as denominator but other studies (e.g. Zimmerman, 1983; Gupta and Newberry, 1997; Singh et al., 1987) take into account the cash flow from operations. Since different adopted ECITR estimations may result to conflicting findings, latest studies (Derashid and Zhang, 2003; Richardson and Lanis, 2007) take into consideration more than one ECITR method estimations into their empirical analysis, in order to control the robustness of their results.

Prior research in the field of ECITR has indicated that the ECITR may be differentiated, for instance, across either industrial sectors or the adopted corporate tax system (Derashid and Zhang, 2003; Stamatopoulos et al., 2019). This fact may be attributed to specific firm characteristics, such as firm size, financial leverage, capital intensity, firm performance, usually in the form of return on assets (Callihan 1994; Gupta and Newberry, 1997; Stamatopoulos et al., 2019). Based on a multivariate approach and longitudinal data Gupta and Newberry (1997) assess whether firm-size, profitability, capital structure, and asset mix influence the effective tax rates. Richardson and Lanis (2007) have determined these firm-specific variables by providing particular definitions for each one of them. For instance, they consider that the firm size is measured as the natural logarithm of total assets, at book value. Financial leverage, which indicates the firms' capital structure, is measured as the long-term debt divided by total assets, both at book values. They also take into account the firm's asset mix in their analysis. They categorize it in three major proxies: i) Capital intensity which is measured as the net property, plant and equipment divided by total assets, both at book values, ii) Inventory intensity which is measured as inventory divided by total assets, both at book values and iii) Research and Development (R\&D) intensity which is as R\&D 
expenditure divided by net sales.

The empirical research in ECITR also takes into consideration some of the so-called control variables which may contribute to ECITR fluctuations even in the same economy (Richardson and Lanis, 2007). Studies (Wilkie, 1988; Gupta and Newberry, 1997) have found that changes in book income may influence ECITR because the tax incentive (e.g. depreciation) is not related proportionately to book income. It is worth to be mentioned that the tax incentives are considered to be responsible for the divergence of book income from the taxable income (Wilkie, 1988). Richardson and Lanis (2007) use the Return on Assets (ROA) as an indicator for firm operating results. They measure ROA as pre-tax income divided by total assets being in agreement with Gupta and Newberry (1997) evidence that there is a positive relation between ROA and ECITR. The prior research has also ascertained that industrial sector is another important control variable which is assessed in the empirical analysis of ECITR determination (Richardson and Lanis, 2007; Omer et al., 1993; McIntyre and Nguyen, 2000; Derashid and Zhang, 2003). The influence of industrial sector seems to be significant considering the fact that some selected firms and sectors may have favourable treatment by the government as it concerns the tax burden due to developed lobby between these firms and government (Derashid and Zhang, 2003). Some studies have pointed out this issue. More specifically, Harberger (1959) and Rosenberg (1969) find that certain industrial sector (farming, textiles, petroleum, coal products, and real estate) have favourable tax treatment concerning other sectors. To similar findings conclude Omer et al. (1993) who ascertain different tax treatment between firms in the pharmaceutical sector and those in the petroleum sector. McIntyre and Nguyen (2000) observe that there is a great variance of the effective tax rate among the industrial sectors in the U.S. Oil companies has the lowest effective tax rate than all the other industrial sectors.

Discussing initially the relation ECITR and firm size, we find that there are two different major views about their association. According to the political cost theory, as a firm appears to be large and prosperous the higher is the possibility to be taxed heavier than the other firms. As Watts and Zimmerman (1986) mention, this kind of firms seems to be the great 'victim' of regulatory actions implemented by the government. Zimmerman (1983) supports the view that since these 'prosperous' firms are taxed heavier, these high taxes are a kind of political cost borne by these firms. Subsequently, this theory concludes that higher-income firms are charged with higher ECITR. According to the alternative view of the political power theory, the tax burden for the largest firms is not proportionally the same and "fair" for the tax system. This may be because their owners or managers can influence the government decisions in their favour resulting to lower ECITR (Siegfried, 1972). Researches in effective tax rates determination have indicated that the association between the firm size and ECITR may not always coincide. For instance, Zimmerman (1983) claims that ECITR and firm size are positively related using a cash flows-based effective tax rate proxy. Latest studies (Salaudeen and Eze, 2018; Stamatopoulos et al., 2019) also indicate that there exists a positive relation between ECITR and firm size. Stamatopoulos et al. (2019) is in agreement with the view that larger firms in Greece face higher ECITR due to their power to reduce their tax burden. Wang, 
Campbell, and Johnson (2014) point out a significant positive relation between bigger firms and ECITR in the long run. They claim that firms may delay tax payments only in short run by taking advantage of tax code. Fernández-Rodríguez \& Martínez-Arias (2014) analyze the determining factors of effective corporate income tax rates focusing on BRIC (Brazil, Russia, India, and China) countries. They point out that larger firms bear higher tax burden especially in Brazil and China. Wu et al (2012) claim that preferential tax status influences significantly the relation between firm size and effective tax rates. More specifically, they point out that firm size is positively associated with effective tax rates for privately controlled firms and negatively associated for state-controlled firms in case of preferential tax status. Instead, lack of this tax status results to no significant relationship between firm size and effective tax rate. However, other studies (Porcano, 1986; Tran, 1998; Richardson and Lanis, 2007; Kim and Limpaphayom, 1998; Derashid and Zhang, 2003; Balios et al., 2020) conclude to a negative association. Delgado, et al (2012) focusing on the firm size of listed US companies over the period 1992-2009 indicate that smaller companies appear greater tax burden which diminishes as the firm size increases. Fernández-Rodríguez \& Martínez-Arias (2012) study carrying out comparative analysis of the tax burden for listed companies in China and the United States results to similar findings. Some studies (e.g. Holland, 1998) have concluded to mixed results. Kim and Limpaphayom (1998) ascertain that large firms pay lower ETR than small firms in Taiwan, Korea, Malaysia, and Thailand, except for Hong Kong. Gupta and Newberry (1997) argue that these differences are due to sample-specific characteristics. Finally, there are studies (e.g. Wilkinson et al., 2001; Lazăr, 2014 ) which do not ascertain any significant relationship between firm size and ECITR.

The financing structure of a firm or financial leverage is another important factor which can influence the ECITR. Gupta and Newberry (1997) assert that the financing decisions of a firm may change its tax treatment. For example, in the case of debt financing of business operations, where the interest expenditure is tax-deductible, a firm which appears high leverage may pay lower ECITR. On the contrary, this may not occur in the case of equity financing where dividends are not tax-deductible. Empirical studies have found that financial leverage is negatively associated with ECITR (Stickney and McGee, 1982; Porcano, 1986; Gupta and Newberry, 1997; Derashid and Zhang, 2003; Richardson and Lanis, 2007; Salaudeen and Eze, 2018; Delgado et al, 2012; Lazăr, 2014). Fernández-Rodríguez \& Martínez - Arias (2012) support this view that firm with low level of debt appear high ECITR. Instead, they assert that after a certain level of debt, the ECITR decreases even though the leverage increases. Fernández-Rodríguez \& Martínez-Arias (2014) result to negative association between leverage and tax burden in Brazil and China. However, Gupta and Newberry (1997) claim that leverage and ECITR could be positively related in the case that firms, highly-based on debt financing, have high marginal tax rates. Stamatopoulos et al. (2019) find a negative association between ETR and financial leverage only for the under-leveraged firms in Greece. Finally, there are studies (Wilkinson et al., 2001; Balios et al., 2020) which do not ascertain any significant relation between financial leverage and ECITR. Wang, Campbell, and Johnson (2014) result to no significant relation in long-run. Instead, they point out that leverage is positively related to ECITR on a short-term basis. 
The asset mix of a firm may also affect ECITR. Studies (Stickney and McGee, 1982; Stamatopoulos et al., 2019; Salaudeen and Eze, 2018; Fernández-Rodríguez \& Martínez-Arias, 2012; Balios et al., 2020) argue that firms with higher capital intensity appear lower ECITR. Fernández-Rodríguez \& Martínez-Arias (2014) indicate that capital intensive firms bear lower tax burden in Russia. Taxpayers may write-off the cost of depreciable assets due to tax incentives in the case of accelerated depreciation provisions and investment allowances. Thereafter, as higher is the proportion of fixed assets to total assets the higher is the cost of depreciable assets and finally the lower is the ECITR (Richardson and Lanis, 2007; Gupta and Newberry, 1997; Stickney and McGee, 1982; Porcano, 1986; Derashid and Zhang, 2003; Lazăr, 2014).

On the contrary, since inventory and capital intensity are substitutes, firms characterized by inventory intensity have higher ECITR (Zimmerman, 1983; Gupta and Newberry, 1997; Richardson and Lanis, 2007; Salaudeen and Eze, 2018; Fernández-Rodríguez \& Martínez-Arias, 2012). Other studies (Stamatopoulos et al. 2019) indicate that exists a significant and negative association between inventory intensity and ECITR. Stamatopoulos et al. (2019) attribute this relation to the fact that increases in inventory ( if inventory growth is higher than sales growth) may result to lower prices and subsequently to lower sales revenue, lower net income and finally lower tax returns. Fernández-Rodríguez \& Martínez-Arias (2014) find that more inventory intensive firms bear lower tax burden in India. However, studies (Derashid and Zhang, 2003; Balios et al., 2020) find no evidence of significant relation between ECITR and inventory intensity.

Finally, the empirical research (e.g. Gupta and Newberry, 1997; Richardson and Lanis, 2007) has indicated that R \& D-intensive firms appear lower ECITR due to the relevant investment tax shield. Evers et al. (2015) assess the effect of are operating Intellectual Property (IP) Box regimes on effective average tax rates for 12 European countries. They find out that these regimes allow expenses to be deducted at the ordinary corporate income tax rate resulting in substantial reductions in effective average tax rates.

Previous studies have also proved that a firm's performance, measured by return on assets, influences the ECITR. However, according to empirical evidence, the results vary. For instance, studies (Derashid and Zhang, 2003; Salaudeen and Eze, 2018; Balios et al., 2020) indicate that the firm's performance affects in the opposite direction the ECITR. Nevertheless, studies (Wilkinson et al., 2001; Salaudeen and Eze, 2018; Fernández-Rodríguez \& Martínez-Arias, 2012; Lazăr, 2014; Fernández-Rodríguez \& Antonio Martínez-Arias, 2014) claim that more profitable firms pay higher ECITR.

The investment opportunities of a firm is another critical factor which has been indicated by the relevant literature (Spooner, 1986; Derashid and Zhang, 2003). It is defined as the Market-to-Book (MktBook) value [i.e. (market price of share) / (book value of outstanding shares, Derashid and Zhang, 2003)]. They ascertain that Market-to-Book Value ratio and ECITR are positively related signalling that high-MktBook firms have higher ECITR than other firms. 
Regarding the association between ECITR and industrial sector there seems to be extended empirical research on this field (e.g., Gupta and Newberry, 1997; Kern and Morris, 1992; McIntyre and Nguyen, 2000; Omer et al., 1993; Zimmerman, 1983; Salaudeen and Eze, 2018; Stamatopoulos et al., 2019). However, most of these studies concern U.S. firms. Derashid and Zhang (2003), being one of the exceptions, study the relation between industrial sectors and ECITR based on Malaysian firms sample trading in the Kuala Lumpur Stock Exchange during the 1990-1999 period. They find that there is significant relation but it depends on the industrial sector. For instance, they observe that manufacturing firms, as well as hotels, appear lower effective tax rates in Malaysia during the assessed period. Derashid and Zhang (2003) support this argument by mentioning that the adopted industrial policy by the Malaysian government protects the manufacturing as well as the tourism industrial sector.

The participation (percentage) of government to equity ownership is also analysed, since government ownership may contribute to lower ECITR in the case, for example, of lobby facilitation. Wang, Campbell, and Johnson (2014) indicate that in the long run state controlled firms appear lower tax haven. However, studies (Jaafar and Thornton, 2015) indicate that tax haven operation results to lower effective tax rates for both private and public firms but the effect is greater for private firms. There are also empirical studies (e.g. Derashid and Zhang, 2003; Balios et al., 2020) which indicate that there is not any statistically significant relation to ECITR.

The role of foreign investors to the equity ownership is recognized to affect significantly the ECITR. Empirical research has dealt with this issue. Wilkinson et al. (2001) assessing the dividend imputation effects on New Zealand firms have ascertained that firms, characterized by high-foreign ownership and high dividend payouts, have lower ECITR. This may be justified by the fact that tax rate for dividend of foreign shareholders is higher than that imposed on undistributed profits. However, after the extension of dividend imputation to foreign shareholders, they find that the tax minimizing incentive reduced. Subsequently, the ECITR increased. Wilkinson et al. (2001) also argue that in the case that the firm is highly owned by foreign investors and the dividend payout ratio is low, then the disparity between resident and foreign shareholders tax treatment is not great. Thereafter, the incentives of foreign investors to minimize tax decline. However, other studies (Dyreng et al., 2017) indicate that corporate effective tax rates may decline at approximately the same rate either for multinational or domestic firms. Wang, Campbell, and Johnson (2014) indicate that there is no significant influence of international ownership on ECITR for China publicly listed companies. In similar findings results the study of Balios et al. (2020) for member countries and other non- EU members of the European Union.

\section{Research Methodology}

\subsection{Estimation Model}

In the present study we attempt to investigate what are the determinants of effective corporate tax rate of some of the northern European Union (EU) member countries and some of the southern EU member countries respectively. Considering the literature we ascertain that only 
a few studies have analysed the EU economies, unlike the case of the USA. One of the most recent studies to be involved in assessing the economies of the EU countries is that of Balios et al. (2020). They investigate the determinants of the effective corporate tax rate of some of the European Union (EU) member countries and other non-EU members analyzing the period after the outbreak of the crisis in the Eurozone, i.e. the period 2004-2016. Furthermore, Delgado, Fernandez-Rodriguez \& Martinez-Arias (2014) assess how various factors affect the ECITR in 15 Member States of the European Union during the period 1992-2009. In this study, we extend the analysis taking also into consideration some non-EU countries which appear strong economic cooperation with EU countries over time. Previous literature (Vroom 2010; Delgado et al., 2019) has pointed out that effective tax rate level varies across EU countries. A recent study of Delgado et al. (2019) studying the convergence of the effective corporate tax rates in the European Union (EU-27), classifies the 27 Member States into three clubs: first club comprises France, Malta, Spain and Portugal, with high effective tax rates, second club with medium tax rates, includes Belgium, Germany, Greece, Luxembourg, Italy, Austria, Slovakia, Hungary, Poland and the Czech Republic and finally the third club of low effective rates comprises the rest of the EU countries.

In this study, we take into account additional determinants, as highlighted by the aforementioned relevant literature (see e.g. Richardson \& Lanis, 2007; Derashid \& Zhang, 2003; Wilkinson et al., 2001; Stamatopoulos et al., 2019). Dataset firms come from industrial sectors according to the classification of Delgado et al. (2014): 1. Agriculture, forestry, fishing, 2. Mining, 3. Construction, 4. Manufacturing, 5. Transportation, Telecommunications, Electricity, Gas and Healthcare, 6. Wholesale Trade, 7. Retail Trade and 8. Services.

Previous studies (e.g. Derashid \& Zhang, 2003) have also taken into consideration in their analysis time effects in order to control the effect of the economic conditions during the assessed period. Delgado et al. (2014) examine the period from 1992 to 2009, just before the financial crisis's burst in Eurozone and the debt crisis in the Greek economy. Stamatopoulos et al. (2019) assessing the effect of the financial crisis period on ECITR in Greece, ascertain that the ECITR increases after the beginning of the financial crisis in Greece, period 2018-2014.

The present study aims to analyse the period after the outbreak of the crisis in the Eurozone up today, but including some years before 2009 in the assessed period, for comparative analysis purposes. More specifically, the period 2004-2016 is assessed for both groups of (northern and southern) European economies. Therefore, since our analysis focuses on the impact of the economic crisis in the Eurozone, the sample dataset is separated into two sub-sample periods. The first one concerns the 2004-2009 period, the so-called pre-crisis years. The second sub-sample concerns the 2010-2016 period since 2010 is the starting-point year of the Memorandum in Greece, Member of the Eurozone, and that of the diffusion of an economic crisis in the Eurozone. Thereafter, in the context of the empirical investigation of the South and North EU economies, we assess each group of countries on three periods: $i$. total sample (2004-2016), ii. subsample (2004-2009) and iii. subsample (2010-2016). 
A robustness check is also taken into consideration in our empirical analysis. As we have already mentioned, due to the fact that different adopted ECITR estimations may result to conflicting findings, studies take into consideration more than one ECITR method estimations into their empirical analysis, in order to control the robustness of their results. Thereafter, two alternative estimations of the effective corporate income tax rate are employed in our empirical research. The first alternative ECITR (ECITR2) estimation method is based on the ratio of income taxes to the net cash flow from operating activities taking into account the Richardson and Lanis (2007) robustness check analysis. According to Zimmerman (1983), cash flows from operating activities are used as alternative denominator of the ECITR ratio, since it contributes to the restriction for any systematic differences in accounting method choices that are related to firm size. The second alternative ECITR (ECITR3) estimation method is based on the ratio of income taxes to earnings before interest and taxes (EBIT). This ECITR measure has already taken into account in previous empirical studies (Porcano, 1986; Derashid and Zhang, 2003).

Our empirical investigation is based on three alternative approaches to effective income tax rate:

1. ECITR1: The ratio of the tax liability of the company (tax liability or current expenditure on corporate tax) to the accounting profits before tax.

2. ECITR2: The ratio of income taxes to net cash flow from operating activities.

3. ECITR3: The ratio of income taxes to EBIT.

Our empirical analysis is based on GMM Arellano Bond estimation, with 1st degree lags and 2nd degree lags.

In our empirical analysis, the following regression model is adopted:

$$
\begin{aligned}
& \text { ECITR }_{i, t}=\alpha_{1}+\alpha_{2} \text { FSIZE }_{i, t}+\alpha_{3} \text { FLEVE }_{i, t}+\alpha_{4} \text { CAPINT }_{i, t}+\alpha_{5} \text { INVINT }_{i, t}+ \\
& \alpha_{6} \text { RDINT }_{i, t}+\alpha_{7} \text { ROA }_{i, t}+\alpha_{8} \text { MKBOOK }_{i, t}+\alpha_{9} \text { FOREQUITY }_{i, t}+\alpha_{10} \text { GOVEQUITY }_{i, t}+ \\
& \varepsilon_{i, t}
\end{aligned}
$$

where:

- ECITR: Effective corporate income tax rate.

- FSIZE: Firm size, which is defined as the natural logarithm of total assets, at the book value.

- FLEVE: Financial leverage, which is defined as the ratio of borrowings to the total assets of the firm, at the book value.

- CAPINT: Capital Intensity, determined as the ratio of net fixed assets (land, buildings-facilities and equipment) to total assets, at the book value.

- INVINT: Inventory Intensity, determined as the ratio of inventories to total assets, at the book value.

- RDINT: Research and Development Intensity, which is defined as the ratio of Research and Development expenditure to net sales. 
- ROA: It is the firm's profitability and it is determined as the ratio of earnings before taxes to total assets of the firm.

- MKBOOK: It indicates the investment opportunities of the firm, which are defined as the ratio of current market / commercial value to the book value of the company.

- FOREQUITY: Participation (percentage) of foreign investors to the equity ownership.

- GOVEQUITY: Participation (percentage) of government to equity ownership.

- $\quad$ i: countries

- $\mathrm{t}$ : period

- $\varepsilon$ : error term

\subsection{Sample Selection}

We investigate the determinants of ECITR assessing two sub-samples of firms from all the aforementioned industrial sectors for 16 member countries of the European Union or not. In the literature, there is a strong interest concerning integration and convergence in the EU which analyses not only EU member economies but also a wider European region strongly integrated with the EU. The first sub-sample consists of firms from 12 member countries of "North" European Union (Note 1) and the second sub-sample consists of firms from 4 member countries of "South" European Union (Table 1).

Table 1. Sample selection countries

\begin{tabular}{|c|c|c|c|c|c|c|c|c|c|c|c|}
\hline \multicolumn{12}{|c|}{ Sample Countries } \\
\hline \multicolumn{12}{|c|}{ Northern EU Members } \\
\hline Austria & Belgium & Finland & France & Germany & Hungary & Netherlands & Norway & Poland & Sweden & Switzerland & $\begin{array}{l}\text { United } \\
\text { Kingdom }\end{array}$ \\
\hline \multicolumn{12}{|c|}{ Southern EU Members } \\
\hline Portugal & Greece & Italy & Spain & & & & & & & & \\
\hline
\end{tabular}

Sample data come from Reuters Database. The initial database consists of 81926 firm's data yearly (row series) which is reduced to 20.501, due to the exclusion of firm outliers with negative total equity, covering the period 2004-2016, a period covering both growth and recession. The sub-sample of northern economies consists of 15592 data yearly (row series) and the respective sub-sample of southern economies consists of 4909 firm's data.

\subsection{Descriptive Statistics}

The variables were first analyzed for their location and their dispersion through their parameters: mean value, standard deviation, median, minimum and maximum value. The higher moments (kurtosis and skewness) are also calculated in order to test through the Jarque Bera test the variables' normality. In Table 2 we present the descriptive statistics of all the variables for the years 2004-2016 for the total data sample of northern EU economies. 
Table 2. Descriptive statistics, Northern EU economies

Table 2.a: Descriptive statistics, northern EU economies, total sample period 2004-2016

\begin{tabular}{lcccccccccccc}
\hline & ECITR1 & ECITR2 & ECITR3 & FSIZE & FLEVE & CAPINT & INVINT & RDINT & ROA & MKBOOK FOREQUITY GOVEQUITY \\
\hline Mean & 0.262739 & 0.246872 & 0.269956 & 12.61295 & 0.194884 & 0.207040 & 0.127373 & 0.027261 & 0.086560 & 1.581236 & 0.072778 & 0.009254 \\
\hline Median & 0.274547 & 0.177333 & 0.235526 & 12.31199 & 0.177500 & 0.161350 & 0.103981 & 0.000000 & 0.059700 & 0.994182 & 0.000000 & 0.000000 \\
\hline Maximum & 0.910910 & 674.7500 & 86.00000 & 19.80698 & 0.901900 & 0.966536 & 0.821063 & 1.529152 & 1.464600 & 59.70330 & 0.990000 & 0.930000 \\
\hline Minimum & 0.000000 & -451.0000 & 0.000000 & 4.844187 & 0.000000 & 0.000000 & 0.000000 & 0.000000 & 0.000100 & 0.000244 & 0.000000 & 0.000000 \\
\hline Std. Dev. & 0.161619 & 10.40344 & 1.272136 & 2.370891 & 0.157864 & 0.186115 & 0.124265 & 0.093010 & 0.102830 & 2.449834 & 0.167456 & 0.062812 \\
\hline Skewness & 0.652935 & 31.84612 & 58.88637 & 0.387556 & 0.704796 & 1.162923 & 1.012458 & 9.014587 & 4.484373 & 8.628303 & 3.113323 & 8.764457 \\
\hline Kurtosis & 4.391715 & 2879.653 & 3821.700 & 2.744317 & 3.127245 & 4.136191 & 3.921886 & 108.1623 & 32.95340 & 123.3083 & 12.91831 & 90.64980 \\
\hline Jarque-Bera & 2366.194 & $5.17 E+09$ & $9.35 \mathrm{E}+09$ & 432.7910 & 1301.374 & 4353.087 & 3215.955 & 7395909 & 626670.1 & 9596803. & 85149.27 & 4960636. \\
\hline Probability & 0.000000 & 0.000000 & 0.000000 & 0.000000 & 0.000000 & 0.000000 & 0.000000 & 0.000000 & 0.0000000 & 0.000000 & 0.000000 & 0.000000 \\
\hline Sum & 4096.619 & 3700.358 & 4150.568 & 196661.1 & 3038.629 & 3228.170 & 1985.999 & 425.0571 & 1331.637 & 24654.63 & 1084.470 & 137.9000 \\
\hline Sum Sq. Dev. & 407.2483 & 1622176 & 24880.21 & 87638.98 & 388.5433 & 540.0519 & 240.7539 & 134.8759 & 162.6606 & 93572.28 & 417.8210 & 58.78522 \\
\hline Observations & 15592 & 14989 & 15375 & 15592 & 15592 & 15592 & 15592 & 15592 & 15384 & 15592 & 14901 & 14901 \\
\hline
\end{tabular}

Table 2.b: Descriptive statistics, northern EU economies, sub-sample period 2004-2009

\begin{tabular}{lcccccccccccc}
\hline & ECITR1 & ECITR2 & ECITR3 & FSIZE & FLEVE & CAPINT & INVINT & RDINT & ROA & MKBOOK FOREQUITY GOVEQUITY \\
\hline Mean & 0.271284 & 0.282916 & 0.305655 & 12.52505 & 0.197063 & 0.211554 & 0.130051 & 0.026787 & 0.090238 & 1.608424 & 0.060060 & 0.008592 \\
\hline Median & 0.285020 & 0.186399 & 0.241424 & 12.19592 & 0.178100 & 0.169124 & 0.107248 & 0.000000 & 0.063900 & 1.061032 & 0.000000 & 0.000000 \\
\hline Maximum & 0.910910 & 423.7500 & 86.00000 & 19.38462 & 0.859000 & 0.963744 & 0.729094 & 1.444811 & 1.464600 & 42.01261 & 0.990000 & 0.870000 \\
\hline Minimum & 0.000000 & -160.0476 & 0.000000 & 6.073045 & 0.000000 & 0.000000 & 0.000000 & 0.000000 & 0.000100 & 0.000273 & 0.000000 & 0.000000 \\
\hline Std. Dev. & 0.162608 & 6.720170 & 1.908448 & 2.358813 & 0.162120 & 0.184532 & 0.123416 & 0.085928 & 0.104890 & 2.298344 & 0.145097 & 0.062265 \\
\hline Skewness & 0.562757 & 35.73265 & 40.96403 & 0.413728 & 0.677203 & 1.116202 & 0.956380 & 8.811228 & 4.699554 & 7.806421 & 3.497101 & 8.631116 \\
\hline Kurtosis & 4.224198 & 2622.874 & 1779.930 & 2.810683 & 2.943064 & 4.034811 & 3.760929 & 108.2119 & 36.81267 & 101.6282 & 16.29131 & 85.05500 \\
\hline Jarque-Bera & 760.3813 & $1.81 \mathrm{E}+09$ & $8.57 \mathrm{E}+08$ & 198.1143 & 505.2787 & 1664.724 & 1165.182 & 3129054. & 335673.2 & 2741689. & 58208.50 & 1814293. \\
\hline Probability & 0.000000 & 0.000000 & 0.000000 & 0.000000 & 0.000000 & 0.000000 & 0.000000 & 0.000000 & 0.000000 & 0.000000 & 0.000000 & 0.000000 \\
\hline Sum & 1790.202 & 1787.179 & 1987.064 & 82652.79 & 1300.422 & 1396.046 & 858.2049 & 176.7658 & 590.2487 & 10613.99 & 371.9500 & 53.21000 \\
\hline Sum Sq. Dev. & 174.4598 & 285234.9 & 23674.14 & 36711.25 & 173.4156 & 224.6758 & 100.4982 & 48.71708 & 71.95313 & 34853.19 & 130.3611 & 24.00592 \\
\hline Observations & 6599 & 6317 & 6501 & 6599 & 6599 & 6599 & 6599 & 6599 & 6541 & 6599 & 6193 & 6193 \\
\hline
\end{tabular}

Table 2.c: Descriptive statistics, northern EU economies, sub-sample period 2010-2016

\begin{tabular}{|c|c|c|c|c|c|c|c|c|c|c|c|c|}
\hline & ECITR1 & ECITR2 & ECITR3 & FSIZE & FLEVE & CAPINT & INVINT & RDINT & ROA & МКВООК & FOREQUITY & GOVEQUITY \\
\hline Mean & 0.256468 & 0.220616 & 0.243803 & 12.67745 & 0.193284 & 0.203728 & 0.125408 & 0.027609 & 0.083839 & 1.561285 & 0.081824 & 0.009726 \\
\hline Median & 0.268635 & 0.171523 & 0.230865 & 12.40562 & 0.177100 & 0.154694 & 0.100569 & 0.000000 & 0.056900 & 0.945388 & 0.000000 & 0.000000 \\
\hline Maximum & 0.909324 & 674.7500 & 18.92308 & 19.80698 & 0.901900 & 0.966536 & 0.821063 & 1.529152 & 1.223800 & 59.70330 & 0.970000 & 0.930000 \\
\hline Minimum & 0.000000 & -451.0000 & 0.000000 & 4.844187 & 0.000000 & 0.000000 & 0.000000 & 0.000000 & 0.000100 & 0.000244 & 0.000000 & 0.000000 \\
\hline Std. Dev. & 0.160610 & 12.41707 & 0.366480 & 2.377780 & 0.154655 & 0.187209 & 0.124855 & 0.097885 & 0.101199 & 2.555232 & 0.181157 & 0.063197 \\
\hline Skewness & 0.722109 & 28.25406 & 24.41406 & 0.368522 & 0.724256 & 1.198393 & 1.054080 & 9.033614 & 4.308901 & 9.020990 & 2.876750 & 8.855055 \\
\hline Kurtosis & 4.551342 & 2289.122 & 959.4166 & 2.699845 & 3.275238 & 4.215842 & 4.043055 & 105.6933 & 29.58766 & 131.9530 & 11.12908 & 94.37163 \\
\hline Jarque-Bera & 1683.349 & $1.89 \mathrm{E}+09$ & $3.39 \mathrm{E}+08$ & 237.3125 & 814.5947 & 2706.464 & 2072.998 & 4073956. & 287828.8 & 6352947. & 35987.51 & 3143016. \\
\hline Probability & 0.000000 & 0.000000 & 0.000000 & 0.000000 & 0.000000 & 0.000000 & 0.000000 & 0.000000 & 0.000000 & 0.000000 & 0.000000 & 0.000000 \\
\hline Sum & 2306.417 & 1913.179 & 2163.504 & 114008.3 & 1738.207 & 1832.124 & 1127.794 & 248.2913 & 741.3878 & 14040.64 & 712.5200 & 84.69000 \\
\hline Sum Sq. Dev. & 231.9531 & 1336927. & 1191.714 & 50839.33 & 215.0734 & 315.1430 & 140.1737 & 86.15628 & 90.55347 & 58710.64 & 285.7456 & 34.77464 \\
\hline Observations & 8993 & 8672 & 8874 & 8993 & 8993 & 8993 & 8993 & 8993 & 8843 & 8993 & 8708 & 8708 \\
\hline
\end{tabular}

Where ECITR: Effective corporate income tax rate. 1, 2, 3: Three alternative approaches to 
effective income tax rate. FSIZE: Firm size. FLEVE: Financial leverage. CAPINT: Capital Intensity. INVINT: Inventory Intensity. RDINT: Research and Development Intensity. ROA: Return on assets. MKBOOK: current market / commercial value to the book value of the company. FOREQUITY: Participation (percentage) of foreign investors to the equity ownership. GOVEQUITY: Participation (percentage) of government to equity ownership.

Tables 2.a-2.c present the descriptive statistics of the assessed variables of the northern EU economies for the total sample period 2004-2016, the sub-sample period 2004-2009 and sub-sample period 2010-2016, respectively. In all cases, the effective corporate income tax rate (ECITR2, ECITR3), firm size, as well as investment opportunities of the firm variables of the northern EU economies for the total sample period 2004-2016 appear the highest standard deviation. Effective corporate income tax rate (ECITR2, ECITR3) appear the highest rate of kurtosis. Research and Development Intensity variable and investment opportunities of the firm variables and participation (percentage) of government to equity ownership also exhibit a high rate of kurtosis.

Furthermore, the degree of deviation of the time series distribution from normality is assessed. We examine the existence of positive or negative asymmetry (kurtosis), i.e. the presence of extreme values which not compatible with the normal distribution, using the Jarque-Bera test. This test calculates the asymmetry and kurtosis based on the sample data and then compares them with the theoretical values of the normal distribution that is zero, since in the normal distribution there is no asymmetry and kurtosis. The basic assumption is $\mathrm{H}_{0}$ : Asymmetry and kurtosis equal to zero (normal distribution of time series) and the alternative $\mathrm{H}_{1}$ : Asymmetry and kurtosis different from zero (abnormal distribution of time series). According to Table 2.a, for all assessed variables, the probability is less than $5 \%$, so the $\mathrm{H}_{0}$ case of normality is rejected.

In Table 3 we present the descriptive statistics of all the variables for the years 2004-2016 of southern EU economies.

Table 3. Descriptive statistics, Southern EU economies

Table 3.a: Descriptive statistics, southern EU economies, total sample period 2004-2016

\begin{tabular}{|c|c|c|c|c|c|c|c|c|c|c|c|c|}
\hline & ECITR1 & ECITR2 & ECITR3 & FSIZE & FLEVE & CAPINT & INVINT & RDINT & ROA & МКВООК & FOREQUITY & OVEQUITY \\
\hline Mean & 0.287168 & 0.229112 & 0.528928 & 12.74083 & 0.301607 & 0.312886 & 0.118961 & 0.007666 & 0.059726 & 1.156127 & 0.043302 & 0.018958 \\
\hline Median & 0.281878 & 0.163925 & 0.230126 & 12.47234 & 0.299800 & 0.272853 & 0.086459 & 0.000000 & 0.045000 & 0.620586 & 0.000000 & 0.000000 \\
\hline Maximum & 0.912680 & 417.3448 & 918.8788 & 18.92388 & 0.908500 & 0.971891 & 0.700401 & 0.894296 & 1.176100 & 35.92912 & 1.000000 & 0.760000 \\
\hline Minimum & 0.000000 & -278.5000 & 0.000000 & 6.917706 & 0.000000 & 0.000000 & 0.000000 & 0.000000 & 0.000000 & 0.000195 & 0.000000 & 0.000000 \\
\hline Std. Dev. & 0.185877 & 8.056222 & 13.26164 & 2.048735 & 0.181447 & 0.221047 & 0.117169 & 0.045478 & 0.064884 & 2.033383 & 0.132787 & 0.093696 \\
\hline Skewness & 0.671889 & 20.59044 & 68.68887 & 0.461918 & 0.219079 & 0.594659 & 1.222461 & 12.47810 & 4.907340 & 6.730621 & 4.312514 & 5.655398 \\
\hline Kurtosis & 3.512563 & 1842.964 & 4756.095 & 2.947489 & 2.540619 & 2.529932 & 4.489721 & 195.4487 & 46.97070 & 70.76251 & 23.56004 & 36.43683 \\
\hline Jarque-Bera & 423.0863 & $6.66 \mathrm{E}+08$ & $4.56 \mathrm{E}+09$ & 175.1350 & 82.43314 & 334.5164 & 1676.610 & 7702897. & 409840.4 & 976269.9 & 95982.97 & 240573.3 \\
\hline Probability & 0.000000 & 0.000000 & 0.000000 & 0.000000 & 0.000000 & 0.000000 & 0.000000 & 0.000000 & 0.000000 & 0.000000 & 0.000000 & 0.000000 \\
\hline Sum & 1409.706 & 1081.179 & 2558.425 & 62544.75 & 1480.591 & 1535.959 & 583.9774 & 37.63131 & 289.4345 & 5675.427 & 200.6600 & 87.85000 \\
\hline Sum Sq. Dev. & 169.5736 & 306211.0 & 850512.7 & 20600.42 & 161.5863 & 239.8141 & 67.38018 & 10.15077 & 20.39713 & 20292.84 & 81.69088 & 40.67307 \\
\hline Observations & 4909 & 4719 & 4837 & 4909 & 4909 & 4909 & 4909 & 4909 & 4846 & 4909 & 4634 & 4634 \\
\hline
\end{tabular}


Table 3.b: Descriptive statistics, southern EU economies, sub-sample period 2004-2009

\begin{tabular}{|c|c|c|c|c|c|c|c|c|c|c|c|c|}
\hline & ECITR1 & ECITR2 & ECITR3 & FSIZE & FLEVE & CAPINT & INVINT & RDINT & ROA & МКВООК & FOREQUIT & GOVEQUITY \\
\hline Mean & 0.300346 & 0.455908 & 0.296770 & 12.78689 & 0.292946 & 0.330753 & 0.125502 & 0.006522 & 0.062640 & 1.322311 & 0.025578 & 0.013538 \\
\hline Median & 0.292157 & 0.181310 & 0.232198 & 12.48790 & 0.297300 & 0.292415 & 0.094067 & 0.000000 & 0.049700 & 0.849961 & 0.000000 & 0.000000 \\
\hline Maximum & 0.912680 & 417.3448 & 14.98851 & 18.85376 & 0.830700 & 0.971891 & 0.700401 & 0.651915 & 0.679900 & 26.21909 & 1.000000 & 0.750000 \\
\hline Minimum & 0.000000 & -38.68750 & 0.000000 & 8.270781 & 0.000000 & 0.000892 & 0.000000 & 0.000000 & 0.000400 & 0.016020 & 0.000000 & 0.000000 \\
\hline Std. Dev. & 0.176256 & 9.785417 & 0.663533 & 1.954616 & 0.170365 & 0.219828 & 0.116201 & 0.035749 & 0.059875 & 1.744402 & 0.089329 & 0.076730 \\
\hline Skewness & 0.659018 & 39.61497 & 14.40685 & 0.572105 & 0.138147 & 0.560724 & 1.161641 & 11.93117 & 3.839380 & 5.203302 & 5.461798 & 6.309359 \\
\hline Kurtosis & 3.849739 & 1677.068 & 262.5122 & 3.008508 & 2.515874 & 2.512982 & 4.337365 & 182.0424 & 27.18089 & 46.04624 & 38.12143 & 45.22109 \\
\hline Jarque-Bera & 218.7731 & $2.31 \mathrm{E}+08$ & 5993879. & 116.4723 & 27.64076 & 132.9778 & 639.2709 & 2902317. & 56804.64 & 174471.8 & 112173.0 & 161011.9 \\
\hline Probability & 0.000000 & 0.000000 & 0.000000 & 0.000000 & 0.000001 & 0.000000 & 0.000000 & 0.000000 & 0.000000 & 0.000000 & 0.000000 & 0.000000 \\
\hline Sum & 641.2395 & 898.1387 & 626.1848 & 27300.00 & 625.4396 & 706.1574 & 267.9472 & 13.92444 & 132.6714 & 2823.134 & 50.90000 & 26.94000 \\
\hline Sum Sq. Dev. & 66.29489 & 188540.4 & 928.5408 & 8152.999 & 61.93745 & 103.1240 & 28.81465 & 2.727193 & 7.589443 & 6493.631 & 15.87149 & 11.71009 \\
\hline Observations & 2135 & 1970 & 2110 & 2135 & 2135 & 2135 & 2135 & 2135 & 2118 & 2135 & 1990 & 1990 \\
\hline
\end{tabular}

Table 3.c: Descriptive statistics, southern EU economies, sub-sample period 2010-2016

\begin{tabular}{|c|c|c|c|c|c|c|c|c|c|c|c|c|}
\hline & ECITR1 & ECITR2 & ECITR3 & FSIZE & FLEVE & CAPINT & INVINT & RDINT & ROA & МКВООК & FOREQUITY & GOVEQUITY \\
\hline Median & 0.269178 & 0.153271 & 0.227361 & 12.45162 & 0.303200 & 0.257290 & 0.079351 & 0.000000 & 0.041600 & 0.429653 & 0.000000 & 0.000000 \\
\hline Maximum & 0.907637 & 86.00000 & 918.8788 & 18.92388 & 0.908500 & 0.941879 & 0.676553 & 0.894296 & 1.176100 & 35.92912 & 1.000000 & 0.760000 \\
\hline Minimum & 0.000000 & -278.5000 & 0.000000 & 6.917706 & 0.000000 & 0.000000 & 0.000000 & 0.000000 & 0.000000 & 0.000195 & 0.000000 & 0.000000 \\
\hline Skewness & 0.708097 & -29.09649 & 51.64709 & 0.401433 & 0.243964 & 0.630160 & 1.278245 & 11.95506 & 5.455842 & 7.255811 & 3.682540 & 5.213360 \\
\hline Kurtosis & 3.339733 & 1249.817 & 2686.425 & 2.881981 & 2.491017 & 2.553956 & 4.639857 & 174.2612 & 55.41294 & 75.40271 & 17.39631 & 30.95926 \\
\hline Jarque-Bera & 245.1549 & $1.78 \mathrm{E}+08$ & $8.19 \mathrm{E}+08$ & 76.11420 & 57.46087 & 206.5894 & 1066.230 & 3456183 . & 325789.2 & 630245.8 & 28808.37 & 98096.45 \\
\hline Probability & 0.000000 & 0.000000 & 0.000000 & 0.000000 & 0.000000 & 0.000000 & 0.000000 & 0.000000 & 0.000000 & 0.000000 & 0.000000 & 0.000000 \\
\hline
\end{tabular}

Where ECITR: Effective corporate income tax rate. 1, 2, 3: Three alternative approaches to effective income tax rate. FSIZE: Firm size. FLEVE: Financial leverage. CAPINT: Capital Intensity. INVINT: Inventory Intensity. RDINT: Research and Development Intensity. ROA: Return on assets. MKBOOK: current market / commercial value to the book value of the company. FOREQUITY: Participation (percentage) of foreign investors to the equity ownership. GOVEQUITY: Participation (percentage) of government to equity ownership.

Tables 3.a-3.c present the descriptive statistics of the assessed variables of the southern EU economies for the total sample period 2004-2016, the sub-sample period 2004-2009 and sub-sample period 2010-2016, respectively. In all cases, the effective corporate income tax rate (ECITR2, ECITR3 (Note 2)), firm size, as well as investment opportunities of the firm variables of the northern EU economies for the total sample period 2004-2016 appear the highest standard deviation. Effective corporate income tax rate (ECITR2, ECITR3) appear the highest rate of kurtosis. Research and Development Intensity variable and investment opportunities of the firm variables, participation of government to equity ownership, firm's 
profitability (ROA) and participation of foreign investors to the equity ownership also exhibit high rate of kurtosis. Furthermore, the Jarque-Bera test indicates that for all assessed variables the probability is less than $5 \%$, so the $\mathrm{H}_{0}$ case of normality is rejected.

\section{Empirical Results}

We estimate model (1) with the two-step generalized method of moments (GMM) of Arellano and Bover (1995) and Blundell and Bond (1998) transformed in first-differences in order to hand cross-section fixed effects. We account for cross-section fixed effects by performing first difference estimation. We use one lag for the instruments in the GMM estimation and robust (to small samples) standard errors of Windmeijer (2005). The estimation method is designed for big $\mathrm{N}$ and small $\mathrm{T}$ dynamic panels with high autoregressive parameter, and while it requires the error term $\varepsilon_{i, t}$ to have no autocorrelation (so that the moments conditions are satisfied for performing GMM), it does not restrict it to be homoskedastic. Fernández-Rodríguez \& Martínez-Arias (2014) apply GMM difference estimator in their empirical investigation of the determinants of the effective corporate income tax rates for listed companies in the BRIC countries. They adopt this methodology in order to control to control for the adjustment effective tax rates, unobserved heterogeneity, and potential endogeneity of the explanatory variables.

\subsection{Empirical Results for Total Sample Period 2004-2016: North vs South}

Having determined the appropriate panel data model we estimate it based on the two-step system generalized method of moments (GMM) as it concerns northern and southern EU economies for the total sample period (2004-2016). Regarding the dependent variable, i.e. the ECITR, we take into account in our empirical analysis the three alternative approaches to effective income tax rate (ECITR1, ECITR2, ECITR3) (Note 3).

Table 4. Results of the estimation of two-step GMM unbalanced paned data model, ECITR1.

Dependent variable is ECITR1. Period panel data estimation 2004-2016.

Total panel (unbalanced) observations for northern EU economies: 11686.

Total panel (unbalanced) observations for southern EU economies: 3589.

\begin{tabular}{llll}
\hline Explanatory variables & Countries & Coefficient (Standard error) & t-Statistic (p-value) \\
\hline FSIZE & North & -0.264592 & -10.22423 \\
\hline & $(0.025879)$ & $(0.0000)$ \\
\hline & South & -0.235448 & -4.452356 \\
\hline & $(0.052882)$ & $(0.0000)$ \\
\hline
\end{tabular}




\begin{tabular}{|c|c|c|c|}
\hline FLEVE & North & -0.126154 & -0.866515 \\
\hline & & $(0.145588)$ & $(0.3862)$ \\
\hline & South & -0.280197 & -1.782517 \\
\hline & & $(0.157192)$ & $(0.0747)$ \\
\hline \multirow[t]{4}{*}{ CAPINT } & North & -1.384946 & -3.424119 \\
\hline & & $(0.404468)$ & $(0.0006)$ \\
\hline & South & 0.633900 & 1.851860 \\
\hline & & $(0.342304)$ & $(0.0641)$ \\
\hline \multirow[t]{4}{*}{ INVINT } & North & 0.201517 & 0.679174 \\
\hline & & $(0.296709)$ & $(0.4970)$ \\
\hline & South & 1.939746 & 4.611005 \\
\hline & & $(0.420678)$ & $(0.0000)$ \\
\hline \multirow[t]{4}{*}{ RDINT } & North & -1.185449 & -3.247413 \\
\hline & & $(0.365044)$ & $(0.0012)$ \\
\hline & South & 0.532088 & 4.038640 \\
\hline & & $(0.131749)$ & $(0.0001)$ \\
\hline \multirow[t]{4}{*}{ ROA } & North & -0.545966 & -6.756607 \\
\hline & & $(0.080805)$ & $(0.0000)$ \\
\hline & South & -0.801542 & -3.878454 \\
\hline & & $(0.206665)$ & $(0.0001)$ \\
\hline \multirow[t]{3}{*}{ MKBOOK } & North & 0.004700 & 1.249655 \\
\hline & & $(0.003761)$ & $(0.2115)$ \\
\hline & South & 0.003342 & 0.445680 \\
\hline
\end{tabular}




\begin{tabular}{|c|c|c|c|}
\hline & & $(0.007500)$ & $(0.6559)$ \\
\hline \multirow[t]{4}{*}{ FOREQUITY } & North & 0.053397 & 0.494619 \\
\hline & & $(0.107955)$ & $(0.6209)$ \\
\hline & South & -0.307528 & -2.086528 \\
\hline & & $(0.147387)$ & $(0.0370)$ \\
\hline \multirow[t]{5}{*}{ GOVEQUITY } & North & 5.108341 & 4.275476 \\
\hline & & $(1.194801)$ & $(0.0000)$ \\
\hline & South & 0.414244 & 1.536465 \\
\hline & & $(0.269609)$ & $(0.1245)$ \\
\hline & North & South & \\
\hline Mean dependent var & -0.002063 & -0.002461 & \\
\hline S.D. dependent var & 0.156069 & 0.184873 & \\
\hline S.E. of regression & 0.226574 & 0.208111 & \\
\hline Sum squared resid & 599.3964 & 155.0074 & \\
\hline J-statistic & 386.3263 & 170.9600 & \\
\hline Prob(J-statistic) & 0.000000 & 0.000000 & \\
\hline Instrument rank & 86 & 86 & \\
\hline
\end{tabular}

The estimation results from Table 4 as it concerns both northern and southern EU economies for the total sample period (2004-2016) show that the effective corporate income tax rate is negatively related to the firm size. This finding is in agreement with previous literature (Porcano, 1986; Tran, 1998; Richardson and Lanis, 2007; Kim and Limpaphayom, 1998; Derashid and Zhang, 2003; Balios et al., 2020) which also concludes to a negative association.

Effective corporate income tax rate is not significantly related to the financial leverage as it concerns northern EU economies. The empirical results for southern EU economies indicate that effective corporate income tax rate is negatively related to the financial leverage (at $10 \%$ significance level). Several studies (Stickney and McGee, 1982; Porcano, 1986; Gupta and 
Newberry, 1997; Derashid and Zhang, 2003; Richardson and Lanis, 2007; Salaudeen and Eze, 2018; Stamatopoulos et al., 2019) also find that effective corporate income tax rate is negatively related to the financial leverage. However, there are studies (Wilkinson et al., 2001; Balios et al., 2020) which do not ascertain any significant relation between financial leverage and ECITR.

Furthermore, there is statistically significant negative relationship between the effective corporate income tax rate and capital intensity for northern EU economies. This evidence is in agreement with the findings of other studies (Richardson and Lanis, 2007; Gupta and Newberry, 1997; Stickney and McGee, 1982; Porcano, 1986; Derashid and Zhang, 2003; Salaudeen and Eze, 2018; Stamatopoulos et al., 2019; Balios et al., 2020). However, the relative estimations for southern EU economies appear a significant positive relationship between the effective corporate income tax rate and capital intensity (at 10\% significance level).

The effective corporate income tax rate for both northern and southern EU economies is negatively related to return on assets. This finding is in agreement with previous literature that points out an opposite relation between ROA and ECTR (Derashid and Zhang, 2003; Salaudeen and Eze, 2018; Balios et al., 2020).

Effective corporate income tax rate for northern EU economies is not significantly related to inventory intensity. Derashid and Zhang (2003) as well as Balios et al. (2020) find no evidence of significant relation between ECITR and inventory intensity. However, effective corporate income tax rate for southern EU economies is positively affected by inventory intensity. This finding is in agreement with other researchers' studies (e.g. Zimmerman, 1983; Gupta and Newberry, 1997; Richardson and Lanis, 2007; Salaudeen and Eze, 2018), who have pointed out that firms characterized by inventory intensity have higher ECITR.

Moreover, the empirical results for northern EU economies indicate that there is a significant negative relation between effective corporate income tax rate and Research and Development (R\&D) intensity. Other studies (e.g. Gupta and Newberry, 1997; Richardson and Lanis, 2007; Evers et al., 2015) supporting this argument, have indicated that R \& D-intensive firms appear lower ECITR due to the relevant investment tax shield. However, effective corporate income tax rate for southern EU economies is positively related to R\&D intensity.

The investment opportunities of a firm, expressed by the market to book value index, are not related to effective corporate income tax rate for both northern and southern EU economies, being in contrast with other researchers. Other Studies (Spooner 1986; Derashid and Zhang, 2003) indicate that high-Market to Book firms have higher ECITR than other firms.

Effective corporate income tax rate for northern EU countries is not significantly influenced by the participation of foreign investors to the equity ownership. This finding is in agreement with previous literature (Dyreng et al., 2017; Balios et al., 2020). Dyreng et al. (2017) indicate that corporate effective tax rates may decline at approximately the same rate either for multinational or domestic firms. However, effective corporate income tax rate for 
southern EU economies is negatively influenced by the participation of foreign investors to equity ownership. This finding is in agreement with previous literature (Wilkinson et al., 2001) claiming that firms, characterised by high-foreign ownership and high dividend payouts, have lower ECITR.

The participation of government to equity ownership affects positively the effective corporate income tax rate for northern EU economies. Other studies (Jaafar and Thornton, 2015) indicate that tax haven operation results to lower effective tax rates for both private and public firms but the effect is greater for private firms. However, the participation of government to equity ownership does not affect the effective corporate income tax rate in the case of southern EU economies. There are empirical studies (e.g. Derashid and Zhang, 2003; Balios et al., 2020) which result to the same argument indicating that there is not any statistically significant relation to ECITR.

The two-step system GMM methodology is repeated for both sub-sample periods based on ECITR1. Furthermore, alternative ECITR estimation measures (ECITR2, ECITR3) are adopted in the econometric model for total sample as well as for both sub-sample datasets and are provided on request.

\subsection{A Time-Period Comparison Analysis for Northern and Southern EU Economies}

We prefer not to discuss the empirical results between northern and southern EU economies for each time-period analytically but to compare relative estimations between the 2004-2009 period, the so-called pre-crisis years and the 2010-2016 period. 2010 is the starting-point year of the Memorandum in Greece, the first memorandum for a Member of the Eurozone, and that of the diffusion of an economic crisis in the Eurozone.

Table 5. A comparison analysis between pre-crisis and crisis time-periods, ECITR1.

Dependent variable is ECITR1.

\begin{tabular}{llll}
\hline Explanatory variables & Countries & Period 2004-2009 & Period 2010-2016 \\
\hline FSIZE & North & $(-)^{* * *}$ & $(-)^{* * *}$ \\
\hline SLEVE & Nouth & $(+)$ & $(-)$ \\
\hline Sorth & $(+)$ & $(+)^{* *}$ \\
\hline CAPINT & South & $(-)^{* * *}$ & $(+)$ \\
\hline & North & $(-)^{*}$ & $(-)^{*}$ \\
\hline
\end{tabular}




\begin{tabular}{llll}
\hline INVINT & North & $(+)^{* *}$ & $(+)$ \\
\hline South & $(-)$ & $(-)^{* *}$ \\
\hline RDINT & North & $(+)$ & $(+)$ \\
\hline ROA & Nouth & $(-)^{* *}$ & $(+)^{* *}$ \\
\hline MKBOOK & South & $(-)^{* * *}$ & $(-)^{*}$ \\
\hline North & $(+)$ & $(-)$ \\
\hline FOREQUITY & South & $(-)^{* *}$ & $(-)^{* * *}$ \\
\hline North & $(-)^{* *}$ & $(-)$ \\
\hline South & $(-)$ & $(+)$ \\
\hline
\end{tabular}

$* * *$ denotes significance at the $1 \%$ level of significance. $* *$ denotes significance at the $5 \%$ level of significance. * denotes significance at the $10 \%$ level of significance.

A comparison analysis as it concerns northern EU economies during 2004-2009 and 2010-2016 sub-sample periods indicate that the effective corporate income tax rate is negatively related to the firm size for both periods. Effective corporate income tax rate for northern EU economies is not significantly related to the financial leverage for 2004-2009 period. However, effective corporate income tax rate is related positively to the financial leverage for northern EU economies for 2010-2016 period. Furthermore, there is statistically significant negative relationship between the effective corporate income tax rate and capital intensity for northern EU economies (at 10\% significance level) for both sub-sample periods. The effective corporate income tax rate is negatively related to return on assets for northern economies during the sub-sample 2004-2009 period. The effective corporate income tax rate is also related negatively to return on assets (at 10\% significance level) during the sub-sample 2010-2016 period. Effective corporate income tax rate for northern EU economies is related positively to inventory intensity during the 2004-2009 period. However, effective corporate income tax rate is not significantly related to inventory intensity during the 2010-2016 period. Moreover, there is not any significant relation between effective corporate income tax rate 
and research and development (R\&D) intensity for northern EU economies for both sub-sample periods. The investment opportunities of a firm, expressed by the market to book value index, are negatively related to effective corporate income tax rate for northern EU economies during the 2010-2016 period. However, the empirical results appear no significant evidence during the 2004-2009 period. Estimations for northern EU economies conclude to a negative relation between effective corporate income tax rate and the participation of foreign investors to the equity ownership during the 2004-2009 period. Effective corporate income tax rate is not significantly influenced by the participation of foreign investors to the equity ownership during the 2010-2016 period. The participation of government to equity ownership does not affect the effective corporate income tax rate for northern EU economies during the 2004-2009 period. However, the participation of government to equity ownership affects positively the effective corporate income tax rate during the 2010-2016 period.

A comparison analysis as it concerns southern EU economies during 2004-2009 and 2010-2016 sub-sample periods indicate that the effective corporate income tax rate is not related to the firm size for both periods. Effective corporate income tax rate is negatively related to the financial leverage for southern EU economies for 2004-2009 period. However, effective corporate income tax rate is not significantly related to the financial leverage for 2010-2016 period. The relative estimations for southern EU economies do not appear a significant relationship between the effective corporate income tax rate and capital intensity for 2004-2009 period. However, estimation results for 2010-2016 period indicate that effective corporate income tax rate is influenced positively by capital intensity. The effective corporate income tax rate is negatively related to return on assets for southern EU economies during the sub-sample 2004-2009 period. However, the effective corporate income tax rate is not significantly related to return on assets during the sub-sample 2010-2016 period. Effective corporate income tax rate is not significantly related to inventory intensity for southern EU economies during the 2004-2009 period. However, the empirical findings result to negative relationship during the 2010-2016 period. There is a significant negative relation between effective corporate income tax rate and research and development (R\&D) intensity for southern EU economies during the 2004-2009 period. However, effective corporate income tax rate is influenced positively by R\&D intensity during the $2010-2016$ period. The investment opportunities of a firm, expressed by the market to book value index, influence negatively the effective corporate income tax rate for southern EU economies during the 2004-2009 period. However, the empirical findings find no significant evidence during the 2010-2016 period. Effective corporate income tax rate is not significantly influenced by the participation of foreign investors to the equity ownership as it concerns southern EU economies during the 2004-2009 period. However, effective corporate income tax rate is negatively influenced by the participation of foreign investors to the equity ownership during the 2010-2016 period. The participation of government to equity ownership does not affect the effective corporate income tax rate for southern EU economies for both sub-sample periods.

A robustness check is also taken into consideration in our empirical analysis. As we have 
already mentioned, due to the fact that different adopted ECITR estimations may result to conflicting findings, studies take into consideration more than one ECITR method estimations into their empirical analysis, in order to control the robustness of their results. Thereafter, two alternative estimations of the effective corporate income tax rate have been employed in our empirical research. The first alternative ECITR (ECITR2) estimation method is based on the ratio of income taxes to the net cash flow from operating activities. The second alternative ECITR (ECITR3) estimation method is based on the ratio of income taxes to earnings before interest and taxes (EBIT). The empirical findings 1 of the alternative estimation measures (ECITR2, ECITR3) are generally in agreement with the initial ECITR (ECITR (Note 4)) results. Minor differences are noticed but they may be due to the ECITR estimation approach itself. The ECITR1 empirical findings are ascertained to be almost in agreement with those of the ECITR3 estimation approach. Any differences may be due to the fact that interest payments are taken into account in the estimation of ECITR3. ECITR2 estimation results also appear minor differences with the initial ECITR1 empirical findings which may be attributed to the fact that only cash flow from operating activities (Note 5$)^{5}$ is taken into consideration in the ECITR estimation.

\section{Concluding Remarks}

Literature has indicated that there is a wide gap between northern and southern EU economies as it concerns in some cases both fiscal as well as structural divergences (Christodoulakis, 2009; De Grauwe, 2012; Neven and Gouymte, 1995; Regan, 2017). Northern EU countries are characterized by more stable and flourishing economies in relation to southern EU countries, which have dealt with financial as well as fiscal adverse conditions appearing prolonged periods of recession and deflation. In this context, we attempt to contribute to the existent literature by identifying the factors that affect the effective corporate income tax rates for the economies of European Union (EU) or not, by categorizing into two groups: northern (EU) countries and southern EU countries. We extend the analysis taking also into consideration some non-EU countries which appearstrong economic cooperation with EU countries over time. The present study aims to analyze the period after the outbreak of the crisis in the Eurozone up today, but including some years before 2009 in the assessed period, for comparative analysis purposes. More specifically, the period 2004-2016 is assessed for both groups of (northern and southern) European economies. We adopt a model with the two-step generalized method of moments (GMM) of Arellano and Bover (1995) and Blundell and Bond (1998) transformed in first-differences in order to hand cross-section fixed effects.

Furthermore, the relation between ECITR and determining factors is ascertained to be less significant (sensitive) during the pre-crisis period in comparison with the respective empirical findings after the outburst of the economic crisis in the European Union. Our empirical findings indicate, in general, that the results of the 2010-2016 period, i.e. crisis period, are closer to those of the initial findings of the total sample (2004-2016) rather than those of the 
pre-crisis years. During the period 2004-2009, it seems that, due to the high market turnover and economic prosperity in most of the EU countries, the determinants of firm's performance are not strongly related to income tax rates.

To summarize, in general, our estimation results point out that the effective corporate income tax rate is variously affected by firm-specific determining factors for both northern and southern economies. This fact seems to be in agreement with the literature above but our empirical analysis is paid attention to the period after the outbreak of the financial crisis in Eurozone. Within the investigated period, we have attempted to have some significant conclusions regarding the impact that had or continues to have the financial crisis in the Eurozone to the firms' performance, particularly after 2010. As we have already mentioned, there is an indisputable and positive coexistence between business profitability and tax burden. The smooth functioning of markets with increased turnover is ensured in a healthy economic environment with "friendly" corporate income tax rates. Taking into account these considerations, we have investigated those factors that determine the effective corporate income tax rates that ensure the sustainability of businesses during the pre-crisis as well as after the outburst crisis period indicating differences which may result to beneficial managerial accounting decisions.

Even though this study has focused on the sample selection of firms by the majority of industrial sectors, our dataset does not include firms by all EU member-countries (northern and southern economies), limiting our conclusion to be generalized for two groups of countries. Thereafter, we may be cautious about the conclusions of this study.

We consider that the present study may be repeated in the future, taking into consideration firms by the rest of the EU member-countries enriching the initial firm's database for both northern and southern group-economies. Furthermore, the empirical analysis may classify the firms by industrial sector attempting to identify the determinants of the effective corporate tax rate by each sector. This may provide useful conclusions about any differences in firms' performance among various industrial sectors.

\section{References}

Arellano, M., \& Bond, S. (1991). Some tests of specification for panel data: Monte Carlo evidence and an application to employment equations. The Review of Economic Studies, 58(2), 277-297. http://doi.org/10.2307/2297968

Arellano, M., \& Bover, O. (1995). Another look at the instrumental variable estimation of error-components models. Journal of Econometrics, 68(1), 29-51. http://doi.org/10.1016/0304-4076(94)01642-D

Balios, D., \& Tantos. S. (2019). The Characteristics of a Fair and Efficient Tax Auditing Information System as a Tool against Tax Evasion: A Theoretical Framework. International Journal of Economics and Management Engineering, 13(6), 777-780. http://doi.org/10.5281/zenodo.3299325 
Balios, D., \& Zaroulea T. (2020). Corporate Governance, Internal Audit and Profitability: Evidence from P.I.G.S. Countries. Journal of Accounting and Auditing: Research \& Practice. http://doi.org/10.5171/2020.668702

Balios, D., Tantos, S., Eriotis, N. \& Vasiliou, D. (2020). Effective corporate income tax rates to the economies of the European Union in the light of the impact of the economic crisis in the Eurozone. International Journal of Economics and Business Administration, 6(1), 1-11.

Blundell, R., \& Bond, S. (1998). Initial conditions and moment restrictions in dynamic panel data models. Journal of Econometrics, 87(1), 115-143. http://doi.org/10.1016/S0304-4076(98)00009-8

Callihan, D. (1994). Corporate effective tax rates: A synthesis of the literature. Journal of Accounting Literature, 12, 1-43.

Christodoulakis, N. (2009). Ten Years of EMU: convergence, divergence and new policy priorities. GreeSE Paper No 22: Hellenic Observatory Papers on Greece and Southeast Europe January 2009. London School of Economics. http://doi.org/10.1177/0027950109338653

De Grauwe, P. (2012). In search of symmetry in the Eurozone. Centre for European Policy Studies. $\quad$ Retrieved from http://www.ceps.eu/system/files/book/2012/05/PB268\%20PDG\%20Symmetry\%20in\%20EZ. pdf

Delgado, F., Fernandez-Rodriguez, E., \& Martinez-Arias, A. (2012). Size and other Determinants of Corporate Effective Tax Rates in US Listed Companies. International Research Journal of Finance and Economics, (98), 160-165.

Delgado, F., Fernandez-Rodriguez, E., \& Martinez-Arias, A. (2014). Effective Tax Rates in Corporate Taxation: a Quantile Regression for the EU. Inzinerine Ekonomika - Engineering Economics, 25(5), 487-496. http://doi.org/10.5755/j01.ee.25.5.4531

Delgado, F., Fernandez-Rodriguez, E., Martinez-Arias, A., \& Presno, M. (2019). Club convergence in the corporate income tax: The case of European effective rates. Physica A, 523, 942-953. http://doi.org/10.1016/j.physa.2019.04.212

Derashid, C., \& Zhang, H. (2003). Effective tax rates and the industry policy hypothesis: evidence from Malaysia. Journal of International Accounting, Auditing and Taxation, 12(1), 45-62. http://doi.org/10.1016/S1061-9518(03)00003-X

Dyreng, S., Hanlon, M., Maydew, E., \& Thornock, J. (2017). Changes in corporate effective tax rates over the past 25 years. Journal of Financial Economics, 124, 441-463. http://doi.org/10.1016/j.jfineco.2017.04.001

Evers, L., Miller, H., \& Spengel, C. (2015). Intellectual property box regimes: effective tax rates and tax policy considerations. International Tax and Public Finance, 22, 502-530. http://doi.org/10.1007/s10797-014-9328-x 
Fairfield, T., \& Jorratt De Luis, M. (2016). Top Income Shares, Business Profits, and Effective Tax Rates in Contemporary Chile. Review of Income and Wealth, 62, 120-144. http://doi.org/10.1111/roiw.12196

Fernández-Rodríguez, E., \& Martínez-Arias, A. (2012). Do Business Characteristics Determine an Effective Tax Rate?. The Chinese Economy, 45(6), 60-83. http://doi.org/10.2753/CES1097-1475450604

Fernández-Rodríguez, E., \& Martínez-Arias, A. (2014). Determinants of the Effective Tax Rate in the BRIC Countries. Emerging Markets Finance and Trade, 50(3), 214-228, http://doi.org/10.2753/REE1540-496X5003S313

Gupta, S., \& Newberry, K. (1997). Determinants of the variability in corporate effect tax rates: Evidence from longitudinal data. Journal of Accounting and Public Policy, 16(1), 1-34. http://doi.org/10.1016/S0278-4254(96)00055-5

Harberger, A. (1959). The corporate income tax: An empirical appraisal. In Proceedings of the Tax Revision Compendium, 1, 231-250. House Ways and Means Committee.

Holland, K. (1998). Accounting policy choice: the relationship between corporate tax burdens and the company size. Journal of Business Finance and Accounting, 25(3-4), 265-288. http://doi.org/10.1111/1468-5957.00187

Jaafar, A., \& Thornton, J. (2015). Tax Havens and Effective Tax Rates: An Analysis of Private versus Public European Firms. The International Journal of Accounting, 50, 435-457. http://doi.org/10.1016/j.intacc.2015.10.005

Johnston, A., \& Regan, A. (2016). European Monetary Integration and the Incompatibility of National Varieties of Capitalism. Journal of Common Market Studies, 54(2), 318-336. http://doi.org/10.1111/jems.12289

Kern, B., \& Morris, M. (1992). Taxes and firm size: the effect of tax legislation during the 1980s. Journal of the American Tax Association, 14(1), 80-96. http://doi.org/10.1016/S1061-9518(98)90005-2

Kim, K., \& Limpaphayom, P. (1998). Taxes and firm size in Pacific-Basin emerging economies. Journal of International Accounting, Auditing \& Taxation, 7(1), 47-68. http://doi.org/10.1016/S1061-9518(98)90005-2

Lazăr, S. (2014). Determinants of the Variability of Corporate Effective Tax Rates: Evidence from Romanian Listed Companies. Emerging Markets Finance and Trade, 50(4), 113-131. http://doi.org/10.2753/REE1540-496X5004S4007

McIntyre, R., \& Nguyen, T. (2000). Corporate income taxes in the 1990s. Washington, DC, USA: Institute on Taxation and Economic Policy. Retrieved from https://itep.org/wp-content/uploads/corp00an.pdf

Neven, D., \& Gouymte, C. (1995). Regional Convergence in the European Community. 


Journal of Common Market $\quad$ Studies, $\quad 3(1), \quad 47-65$.
http://doi.org/10.1111/j.1468-5965.1995.tb00516.x

Omer, T., \& Molloy, K. (1991). Measurement of effective corporate tax rates using financial statements information. The Journal of the American Taxation Association, 13, 57-72.

Omer, T., Molloy, K., \& Ziebart, D. (1993). An investigation of the firm size-effective tax rate relation in the 1980s. Journal of Accounting, Auditing and Finance, 8(2), 167-182. http://doi.org/10.1177/0148558X9300800206

Plesko, G. (2003). An evaluation of alternative measures of corporate tax rates. Journal of Accounting and Economics, 35(2), 201-226. http://doi.org/10.1016/S0165-4101(03)00019-3

Porcano, T. (1986). Corporate tax rates: progressive, proportional or regressive. The Journal of the American Taxation Association, 7(2), 17-31. Retrieved from https://www.econbiz.de/Record/corporate-tax-rates-progressive-proportional-or-regressive-po rcano-thomas/10001024905

Regan, A. (2017). The imbalance of capitalisms in the Eurozone: Can the north and south of Europe converge?. Comparative European Politics, 15, 969-990. http://doi.org/10.1057/cep.2015.5

Richardson, G., \& Lanis, R. (2007). Determinants of the variability in corporate effective tax rates and tax reform: Evidence from Australia. Journal of Accounting and Public Policy, 26(6), 689-704. doi.org/10.1016/j.jaccpubpol.2007.10.003

Rosenberg, L. (1969). Taxation of income from capital, by industry group. In A. C. Harberger \& M. J. Bailey (Eds.), The taxation of income from capital. Washington, DC.

Salaudeen, Y.-M., \& Eze, U.-C. (2018). Firm specific determinants of corporate effective tax rate of listed firms in Nigeria. Journal of Accounting and Taxation, 10(2), 19-28. http://doi.org/10.5897/JAT2017.0288

Sargan, J. (1958). The estimation of economic relationships using instrumental variables. Econometrica, 26(3), 393-415. http://doi.org/10.2307/1907619

Shevlin, T. (1987). Taxes and off-balance-sheet financing: Research and development limited partnership. The Accounting Review, 62(3), 480-509. Retrieved from http://www.jstor.org/stable/247573

Shevlin, T., \& Porter, S. (1992). The corporate tax comeback in 1987: some further evidence. The Journal of the American Tax Association, 14(1), 58-79. Retrieved from https://search.proquest.com/openview/4fee8e80b10eb771e8da9238a20e61ed/1?pq-origsite=g scholar\&cbl $=31656$

Siegfried, J. (1972). The relationship between economic structure and the effect of political influence: empirical evidence from the federal corporation income tax program. Ph.D dissertation. Madison: University of Wisconsin. Retrieved from 
https://books.google.gr/books/about/The_relationship_between_economic_struct.html?id=5H vXAAAAMAAJ\&redir_esc $=y$

Singh, D., Wilder, R., \& Chan, K. (1987). Tax rate in small and large firms. Entrepreneurship Theory and Practice, 12(2), 41-52. http://doi.org/10.1177/104225878701200204

Spooner, G. (1986). Effective tax rates from financial statements. National Tax Journal, 39(3), 293-306. Retrieved from http://www.jstor.org/stable/41792191

Stamatopoulos, I., Hadjidema, S., \& Eleftheriou, K. (2019), Explaining corporate effective tax rates: Evidence from Greece. Economic Analysis and Policy, 62, 236-254. http://doi.org/10.1016/j.eap.2019.03.004

Stickney, C., \& McGee, V. (1982). Effective corporate tax rates. The effect of size, capital intensity, leverage, and other factors. Journal of Accounting and Public Policy, 1(2), 125-152. http://doi.org/10.1016/S0278-4254(82)80004-5

Tran, A. (1998). Causes of the book-tax income gap. Australian Tax Forum, 14(3), 253-286. Retrieved from https://search.informit.com.au/documentSummary;res=IELAPA;dn=200008345

Vroom, A. (2010). Malta - The Combined Effective Corporate Tax Rate in Malta Explained. European Taxation, 50(9).

Wang, Y., Campbell, M., \& Johnson, D. (2014). Determinants of Effective Tax Rate of China Publicly Listed Companies. International Management Review, 10(1), 10-20. Retrieved from https://pdfs.semanticscholar.org/c22f/5cb0e98012284fbed897a2fac7b55c707c2c.pdf

Watts, R., \& Zimmerman, J. (1986). Positive Accounting Theory .Englewood Cliffs, New Jersey, USA: Prentice-Hall.

Wilkie, P. (1988). Corporate average effective tax rates and inferences about relative tax preferences. Journal of the American Tax Association, 10(1), 75-88. Retrieved from http:/connection.ebscohost.com/c/articles/6143732/corporate-average-effective-tax-rates-infe rences-about-relative-tax-preferences

Wilkie, P., \& Limberg, S. (1993). Measuring explicit tax (dis) advantage for corporate taxpayers: An alternative to average effective tax rates. The Journal of the American Taxation Association, 15(1), 46-71.

Wilkinson, B., Cahan, S., \& Jones, G. (2001). Strategies and dividend imputation: the effect of foreign and domestic ownership on average effective tax rate. Journal of International $\begin{array}{lllll}\text { Accounting, } \quad \text { Auditing } \quad \& \quad \text { Taxation, } & 10(2),\end{array}$ http://doi.org/10.1016/S1061-9518(01)00042-8

Windmeijer, F. (2005). A finite sample correction for the variance of linear efficient two-step GMM estimators. Journal of Econometrics, 126(1), 25-51. http://doi.org/10.1016/j.jeconom.2004.02.005 
Wu, L., Wang, Y., Wei Luo, W., \& Gillis, P. (2012). State ownership, tax status and size effect of effective tax rate in China. Accounting and Business Research, 42(2), 97-114. http://doi.org/10.1080/00014788.2012.628208

Zimmerman, J. (1983). Taxes and firm size. Journal of Accounting and Economics, 5(2), 119-149. http://doi.org/10.1016/0165-4101(83)90008-3

\section{Notes}

Note 1. In this empirical study analyzes not only EU member economies but also a wider European region strongly integrated with the EU, such as Switzerland and the case of United Kingdom with the scheduled withdrawal of the United Kingdom (UK) from the European Union (EU), the so-called Brexit.

Note 2. Except from the case of sub-sample period 2004-2009. ECITR3 appears low value of standard deviation.

Note 3. ECITR2 and ECITR3 estimations are provided on request.

Note 4. Empirical results for ECITR2 and ECITR3 estimation measures on request.

Note 5. Cash flow from investing and financing activities are not taken into account.

\section{Glossary}

EU: European Union.

ECITR: Effective Corporate Income Tax Rate.

\section{Copyright Disclaimer}

Copyright for this article is retained by the author(s), with first publication rights granted to the journal.

This is an open-access article distributed under the terms and conditions of the Creative Commons Attribution license (http://creativecommons.org/licenses/by/4.0/) 